\title{
Holy Scripture
}

\section{Canon, Authority, Criticism}

\section{James Barr}

The men of the Bible did not themselves have a Bible to be their supreme guide and authority. Their attitudes to scripture differ greatly from those that were created once the boundaries of scripture were drawn and its contents defined. This book discusses the way in which the canon of scripture was formed and the effects that it has, as well as recent suggestions that the canon should be the guiding principle in interpretation. 'An enormously helpful book.' Church of England Newspaper £13.00 paperback £5.95

\section{Discerning the Mystery}

\section{An Essay on the Nature of Theology Andrew Louth}

The author first examines the presuppositions of the claims of the Enlightenment, with its rejection of the ways of understanding handed down by tradition, and then shows how the traditional ways of theology, especially the Patristic use of allegory in Biblical interpretation, can be seen to retain their validity once the pretensions of the Enlightenment have been exposed. $£ 12.50$

Now in paperback

\section{The Origins of the Christian Mystical Tradition from Plato to Denys}

\section{Andrew Louth}

'A book on spirituality which is trenchant and without any touch of sentimentality.' Henry Chadwick, Times Literary Supplement. 'It is a great merit in this book that it is ready to talk about dogma and indeed tries to unite, in the spirit of the Fathers, doctrine and spirituality. 'Journal of Theological Studies $\mathbf{f 5 . 5 0}$ paperback

Now in paperback

\section{The Spiritual Nature of Man}

\section{Alister Hardy}

Based on the work of the Religious Experience Research Unit in Oxford, The Spiritual Nature of Man was first published in 1979 and aroused widespread interest. 'Readers of this book will feel urged to look at their own inner life and experience... The study of inner space is surely vital to the future of mankind as the exploration of outer space.' The Daily Telegraph f6.25 paperback

\section{Oxford University Press}




\section{NEUE ZEITSCHRIFT FÜR SYSTEMATISCHE THEOLOGIE UND RELIGIONSPHILOSOPHIE}

\section{In collaboration with Jörg Baur - John Powell Clayton H. G. Hubbeling - Hampus Lyttkens - Patrick Masterson Edited by Carl Heinz Ratschow}

1984: Volume 26. Single issue DM 36,-; 1 volume with 3 issues DM 102,-

Contents (Volume 25, 1983)

Hubbeling, H. G.: Das Heilige und das Schöne. Gerardus van der Leeuws Anschauungen über das Verhältnis von Religion und Kunst

Hammond, Guy B.: The Conscience-less Society and Beyond: Perspectives from Erich Fromm and Paul Tillich

SCHWARZ, HANS: Die christologische Forschung in der gegenwärtigen nordamerikanischen Theologie

ALMOND, C.: Rudolf Otto and the Kantian Tradition

CONNELL, DESMOND: Substance and the Interiority of Being

STEINACKER, PETER: Gott, der Grund und Ungrund der Welt. Reflexionen zum Verhältnis von Welterfahrung und Gottesbild am Beispiel der Mystik Jakob Böhmes

RINGLEBEN, J.: Anmerkungen zur Christologie der Glaubenslehre Schleiermachers. Hayo Gerdes $\dagger$

DUDLEY, J. A. J.: The Love of God in Aristotle's Ethics

SCHINZER, Reinhard: Die Bedeutung des Prozesses Jesu

SCHOLZ, FRITHARD: Ontologischer Gottesbeweis?

DALFERTH, INGOLF M.: Existenz und Identifikation. Erwägungen zum Problem der Existenz Gottes im Gespräch mit der Analytischen Philosophie

MAsterson, PATriCK: Ethics and Absolutes in the Philosophy of E. Levinas

PAetzold, Heinz: Mythos als symbolische Form. Zu Ernst Cassirers philosophischer Deutung des Mythos

RobINSON, W.D.: Partial Belief

BAYER, OSWALD: Erhörte Klage

WALTHER, CHRISTLAN: Die Frage nach dem Sinn und der christliche Glaube

DEUSER, HERMANN: Gott - Realität und Erfahrung. Überlegungen im Anschluß an die Religionsphilosophie von Charles S. Peirce

Prices are subject to change 


\section{NOTES FOR CONTRIBUTORS}

r. Contributions and books for review should be sent to the new Editor, Professor S. R. Sutherland, King's College, Strand, London, WC2R 2LS.

2. Articles submitted to the journal should in general be between 5,000 and I0,000 words long, though articles outside these limits will be acceptable if there is some good reason for their exceptional length or brevity. Articles in two or more parts may occasionally be accepted provided each part is independently intelligible. They should normally be in English.

3. Submission of an article is taken to imply that it has not previously been published, or is not being considered for publication elsewhere.

4. Contributions should be clearly typed in double spacing, preferably on $\mathrm{A}_{4}$ paper, with a wide left-hand margin. The typescript should be prepared to accord as closely as possible with the typographical conventions of the journal.

5. Footnotes should be used sparingly: in general, to give sources of direct quotations, references to main authorities on disputable questions, and evidence relied on for a new or unusual conclusion. They should be numbered in one sequence throughout the article, and should preferably be typed in double spacing at the end of the article.

6. Contributors should keep one copy of the typescript for correcting proofs.

7. First proofs may be read and corrected by contributors provided that they can give the Editor an address through which they can be reached without delay and can guarantee to return the corrected proofs to the Editor, by airmail where necessary, within ten days of receiving them.

8. Correction should be kept to an absolute minimum. It should be confined to errors of the typist or printer unless the Editor authorises otherwise.

9. All contributors of articles receive 50 free offprints. Reviewers will receive five or more offprints of their reviews.

10. If rejected manuscripts are to be returned, stamps or international coupons should be sent to cover postage, but it would normally be simpler just to retain a copy.

I 1. Contributors of accepted articles will be asked to assign their copyrights, on certain conditions, to Cambridge University Press, to help protect their material, particularly in the USA. 


\section{Religious Studies}

\section{Volume $20 \quad$ Number $1 \quad$ March 1984}

\section{GONTENTS}

Introduction

OWEN, H. P.

Morality and Christian Theism

SMART, NINIAN

Our Experience of the Ultimate

CANTWELL SMITH, WILFRED

On Mistranslated Booktitles

SMITH, JOHN E.

The External and Internal Odyssey of God in the

Twentieth Century

FINDLAY, J. N.

Identity and Identification

LECLERC, IVOR

God and the Issue of Being

ROBERTS, T. A.

Law, Morality and Religion in a Christian Society

CHATTERJEE, MARGARET

Religion, Understanding, and Sharing Insights

MILES, T. R.

On the Limits to the Use of Force

SUTHERLAND, STEWART R.

Religion, Experience and Privacy

MACKINNON, D. M.

Some Aspects of the Treatment of Christianity by the British Idealists

LIPNER, J. J.

The World as God's 'body : In Pursuit of Dialogue

with Rāmānuja

(C) Cambridge University Press 1984

CAMBRIDGE UNIVERSITY PRESS

The Pitt Building, Trumpington Street, Cambridge CB2 IRP

32 East 57th Street, New York, N.Y. 10022

Religious Studies is indexed in the Religion Index One: Periodicals

Printed in Great Britain at the

University Press, Cambridge 